80(497.11)"19"

811.163.41'26

https://doi.org/10.18485/sj.2020.25.1.16

ИЛИЈАНА Р. ЧУТУРА*

НИНА Б. МАРКОВИТ

Универзитет у Крагујевцу

Факултет педагошких наука у Јагодини
Оригинални научни рад

Примљен: 15. 10. 2019.

Прихваћен: 15. 01. 2020.

\title{
О ЈЕДНОЈ СЕРИЈИ „ФИЛОЛОШКИХ МЕГДАНА” ИЗМЕЂУ МИЛОША АНЪЕЛКОВИЋА И АЛЕКСАНДРА БЕЛИЋА: ЦРТИЦА ИЗ ИСТОРИЈЕ СРПСКОГ КЊИЖЕВНОГ ЈЕЗИКА**
}

Предмет рада јесте дуготрајни сукоб између протојереја Милоша С. Анђелковића и Александра Белића. Сукоб је иницирао прота Анђелковић у време када је био професор јагодинске Учитељске школе. Спорна питања била су филолошка (првенствено везана за правопис и Белићеву студију Дијалекти источне и јужне Србије) али су добијала и карактер националних, чак и националистичких иступа Анђелковића. Осим тога што се водио писаним путем (часописи, дневне новине, брошуре), сукоб се преносио и у београдски Варошки суд и изазивао огромну пажњу филолога, свештенства, професора и студената, али и најшире јавности.

Кључне речи: прота Милош Анђелковић, Александар Белић, часопис Бранич, нормативистика, правопис, српски књижевни језик, Станислав Винавер.

*ilijana.cutura@gmail.com

${ }^{* *}$ Рад је настао у оквиру пројеката 178014 Динамика структура савременог српског језика и 178018 Друштвене кризе и савремена српска књижевност и култура: начионални, регионални, европски и глобални оквир, које финансира Министарство просвете, науке и технолошког развоја Републике Србије.У раду је коришћена грађа из Завичајног музеја у Јагодини (часопис Бранич), као и архивска грађа Факултета педагошких наука у Јагодини (Универзитет у Крагујевцу) који је наследио јагодинску Учитељску школу. 
Готово цела шеста страна новина Правда од 4.10.1927. (бр. 269) посвећена је једном необичном судском рочишту. На почетку текста чији је наслов „Академик г. др. Белић и прота г. Анђелковић” а наднаслов „Један филолошки мегдан" извештач истиче необичност овог догађаја:

„Кад се у судској сали испреда каква љубавна драма, каква необична љубав до смрти, онда је атмосфера пуна плача, суза, узбудљивости, и онда суд личи на извесну романтичну бину са плачевним мелодрамама; али кад се у храму правде чује, као јуче, једна читава филолошка расправа, испуњена самим језикословним терминима, и Караџићима, и Даничићима, онда нам заиста све изгледа необично. Јер, јуче је одаја другог оделења у варошком суду била право филолошко поприште, у толико интересантније што се тицало једне полемике између једног свештеног лица и једног доктора филологије и познатог нашег научника. Заинтересована два свештеника, неколико студената, један београдски књижар били су ту већ и очекивали резултат ове чудне и неравне борбе".

„Неравна борба” окончала се ослобађајућом пресудом за туженога Белића, којег је прота Милош С. Анђелковић, тада начелник Министарства вера у пензији, оптужио „по закону о штампи” за увреду и клевету. Између осталог, преноси Правда, Анђелковић „заступа ћирилицу као азбуку свих Словена”:

Само један наш доктор филологије, вели г. Анђелковић, и професор Универзитета, само г. др. Белић не може рећи да ћирилица треба да буде заједничка за Србе, Хрвате и све Словене у опште.

Г. Милош Анђелковић даље протестује противу Академије Наука што она не устане противу овога и „Академија Наука је много крива што се данас у наш језик и нашу књижевност увлаче страшне језичке и правописне погрешке”.

Белићев бранилац Живко Тадић на крају истиче да је прота у криву ,јер он мисли да је човек добар филолог онај, који је само добар Србин! На овакав начин др. Белић је морао реаговати. Али прво што је требао учинити, то је да га ухвати и да га ишамара, а друго да он тужи суду. Ја бих прво учинио”.

Ово судско рочиште, о којем Правда до детаља извештава, било је само врхунац дводеценијских спорова Анђелковића и Белића, које је прота покренуо 1907. године у првом броју часописа Бранич српског или хрватског језика (са поднасловом „први лингвистички лист, искључиво за исправљање погрешака у језику и правопису српском или хрватском"). Анђелковић је овај часопис покренуо као уредник и власник, а текстове је писао сам. Обрушивши се свом снагом на Белићеву књигу Дијалекти источне и јужне Србије, наставио је да са њим полемише, а свој протест заокружује 1926. године, књижицом од 24 стране Питање о правопису српског или хрватског језика или Кривопис д-ра Александра Белића, професора филологије у београдском университету. Већ на корици, испод наслова, своју публикацију посвећује „најозбиљнијој пажњи Академије Наука и Главног Просветног Савета".

${ }^{1}$ У даљем тексту: Правда. 
Можда је најзанимљивија његова оптужба против Белића била да „дисквалификује и омаловажава” наше највеће филологе. Њу аргументује тиме што је (у правопису из 1923. године) Белић „мењао Д у Т пред словом C” и додаје: „Срећан је г. Белић, колико је тежак, што Вук није данас жив” (Правда). Бескомпромисни Анђелковић, који је преминуо 1931. године, није дочекао Правопис из 1960, где се после тридесет седам година враћа изузетак од једначења по звучности, познат данас и најмлађим основцима: „Ако се $\partial$ нађе испред $c$ или $u$, оно у писму остаје неизмењено, ма у коме се положају у речи налазило" (Правопис 1960: 63). Један од једанаесторице аутора Правописа (чланова Правописне комисије) јесте Александар Белић.

Основни циљ у овоме раду јесте да осветлимо време ових сукоба и изнесемо најзначајније његове елементе: ко је био прота Анђелковић и шта је толико замерао Александру Белићу; шта га је одржало у намери да двадесет година детаљно анализира Белићеве текстове и о њима пише толико да су га противници окарактерисали као „доконог попа”; на које је граматичке и правописне проблеме указивао, и - на крају - како види улогу Академије наука у неговању ћирилице и српског језика.

\section{ПРОТА МИЛОШ С. АНЪЕЛКОВИЋ - ОСНОВНИ ПОДАЦИ О ЖИВОТУ И РАДУ}

Милош С. Анђелковић рођен је 28. маја 1868. у Свилајнцу, а преминуо 25. јуна 1931. године у Београду. Од младости је, што се његовим успехом током школовања потврдило, био изузетан: „Као одличан дипломац београдске Богословије послат је на даље школовање и усавршавање у Русију, где је прво завршио духовну семинарију у Петрограду, а потом и Духовну академију у Кијеву" (Станојловић 2009: 9).

У Српској краљевској мушкој учитељској школи јагодинској прота Милош Анђелковић је као „предавач, суплент и професор” предавао „хришћанску науку, црквено појање, црквено словенско читање и руски језик” (Двадесетпетогодишњица МУШЈ, 41) од 9. новембра 1898. године. За суплента је постављен 21. августа 1900. године (Годишњи извештај 1900/1901: 3), а у звање професора унапређен је „Указом Њ. В. Краља” од 11. 9. 1901. (Годишњи извештај 1901/1902: 3). Више пута је премештан у друге школе и враћан у Јагодину: „Указом је од 1. фебруара 1906. [...] постављен за суплента ове школе синђел г. Платон, суплент Алексиначке мушке учитељске школе, а у тамошњу је учитељску школу г. Милош Анђелковић, свештеник и професор ове школе" (Годишњи извештај 1905/1906 и 1906/1907: 31) да би већ указом од 5. септембра исте године протосинђел Платон добио намештење „професора Реалке у Београду", а Анђелковић, сада као протојереј, враћен у јагодинску школу. Судећи према извештајима, у овој школи је радио до 31. јула 1908. 
године, када је премештен у чачанску гимназију, „а отуда у Нишку гимназију” (Годишњи извештај 1908/1909: 3). Године 1921. постављен је за начелника Министарства вера.

Оно што се свакако може закључити о проти Анђелковићу јесте да је био изузетно вредан посленик на пољу црквених и просветних послова. Сам је покренуо часопис Бранич српског или хрватског језика (у Јагодини, док је радио као професор Мушке учитељске школе јагодинске), написао је „тридесетак веома успелих уџбеника и књига" (Станојловић 2009: 10) (нпр. Историја хришћанске и српске иркве; Догматика православне иркве с апологетичким објашњењима, Хришћанска наука). Аутор је више стотина стручних текстова, а покренуо је и „Глас-први епархијски црквено-књижевни орган у Краљевини Србији" (Исто: 10). Пензионисан је као начелник Министарства вера.

Не може се спорити да је прота Анђелковић јасно и „без длаке на језику" изражавао своје мишљење о низу питања везаних за области његовог интересовања, што је доводило до веома оштрих конфликата са многима. При обављању својих послова свакако је био помало „на своју руку”:

„Године 1906. вршио је ревизију цркава у срезу Расинском нарочити посланик његовог преосвештенства Епископа Нишког Господина Никанора, прота и професор Алексиначке учитељске школе Г. Милош Анђелковић. Шта је и како је нашао није ником па ни свештенику саопштено" (Кубурић 2010: 58).

Остало је забележено и његово оштро противљење постављању Тихона Радовановића за доцента београдског Богословског факултета, које је морало бити изузетно категорично с обзиром на то да је име проте Анђелковића незаобилазно у савременим чланцима о епископу:

„Тихонов рад на факултету обиљежио је спор са протојерејем Милошем Анђелковићем, бившим начелником Министарства вера, који је критички говорио о Тихоновој докторској дисертацији, као и о неким другим његовим радовима. Обраћајући се Ректорату Универзитета у Београду, прота Милош Анђелковић је доводио у питање Тихонов избор у звање доцента, а потом у звање хонорарног наставника. Прота Анђелковић замјерио je Тихону, прије свега, да заступа дарвинизам, да су пророци за њега само визионари, те да је Мојсеј 'творац монотеизма'. Свети архијерејски синод одбацио је ове оптужбе као неозбиљне и неумјесне" (Кострешевић 2012: 182; о овом сукобу в. и Кубат 2008: 8).

У новинама Време, у рубрици „Из суда”, налази се чланак у којем је он опет један од главних актера. Чланак је насловљен „Теолошки спор проте г. Добросава Ковачевића и г. Милоша Анђелковића око једног верског уџбеника" и у њему можемо јасно видети колико је прота заоштравао своје перо у намери да непоколебљиво брани науку и стручну честитост. Новине, наиме, наводе да је „брошуру” коју је објавио поводом спорног уџбеника насловио „Галерија незнања и плагијата”, да је реч „плагијатор” поновио више пута и на суду, додајући јој „епитете: ненадмашан, ординарни”. Своје захтеве веома јасно, са дозом љутње, формулише: „Ја тражим, да прота Ковачевић своју 
професорску диплому окачи на реп мачку треће београдске гимназије, где предаје верску наставу” (Време, од 12.2.1928, стр. 10).

И поводом општих црквених правила прота се оглашавао са једнаком жестином, те је, на пример, његова критика Сергија Тројицког поводом става да је покрет за други свештенички брак „болештина црквеног живота” (Пилиповић 2017: 226) била најоштрија и истрајна: „Милош Анђелковић није напуштао Сергија Тројицког у области брачног права и није му давао уступака ни у каснијим годинама, о чему има и архивски сачуваних писама упућених жалби на разматрање Светом архијерејском синоду Српске православне цркве" (Исто: 226).

Са таквим карактером и веома широким знањем прота Анђелковић непрестано се и неуморно обрушавао и на оне код којих би уочавао немаран однос према српском језику. Историчар Нинослав Станојловић истиче да је „рад Милоша Анђелковића био признат у највишим српским научним круговима, те да су његов рад познавали и поштовали Ватрослав Јагић, Милан Решетар, Стојан Новаковић и многи други научни ауторитети тога времена".

\section{ПРОТА АНЪЕЛКОВИЋ И ЈЕЗИЧКА ПИТАЬА}

О томе колико је Анђелковић био посвећен свом матерњем језику и обузет идејом о његовом неговању и неговању ћирилице, сведочи већ то што је основао часопис Бранич, „први лингвистички лист” који је био намењен „исправљању погрешака”. Дакле, први практично усмерени лингвистички лист код нас покренут је у Јагодини док је Анђелковић радио у Српској краљевској мушкој учитељској школи јагодинској. Међутим, поред рубрика о исправљању погрешака, садржина листа показује да је Анђелковић помно пратио филолошку, уџбеничку и књижевну продукцију и да је својим ставовима и аргументима реаговао на све што му се чинило нарушавањем српског језика и његове норме. Лист је најчешће излазио два пута месечно, вероватно уз велико Анђелковићево залагање да сакупи пренумеранте и тако обезбеди трошкове штампе. На пример, у седмом броју Анђелковић моли да се претплата редовно уплаћује те моли „да се неко не увреди, ако лист не добије после 1 . априла, а није послао претплату" (Бранич 7, стр. 16). Међутим, сама чињеница да је опстајао од средстава претплате говори о томе колико је интересовање за језик морало бити. Часопис је излазио од 1907. до јула 1910. године (до

${ }^{2}$ Текст из којег је преузет цитат носи наслов Јагодина већ 111 година у борби за чистоту српског језика. Аутор је Милун Васић, а текст је објављен на интернет страници Народне библиотеке „Радисав Никчевић” у Јагодини (http:/www.jabooka.org.rs/2018/10/24/jagodina-vec-111godina-u-borbi-za-cistotu-srpskog-jezika/). 
јуна 1908. у Јагодини, а потом у Нишу). Објављено је 37 бројева, а сачувано 35 (Станојловић 2009: 11).

Анђелковић, који је сам писао прилоге за Бранич, ${ }^{3}$ био је изузетно оштрог пера када се радило о актуелној штампаној филолошкој продукцији у Србији. Често напада Српски кьижевни гласник поводом, како каже, језичких, стилских и правописних „накарада” за које наводи низ примера коментаришући их у фуснотама или даљем тексту са великом жестином. Тако ће реченицу „Латао сам се понова са њом љубавнога говора, али та узбуђења и тај говор личили су ономе бледом и безбојном лишћу које са остатком гробне животне силе очајно чами на гранама дрвета из корена ишчупаног" коментарисати само овако: „Слава тебје Боже наш, слава тебје!” (Бранич 7, стр. 12). У истом броју, на следећој страни, закључује: „Штета је велика, што се овај лист растура и ван краљевине Србије, те ће тамо људи мислити, да су остали наши књижевници још неписменији, кад је овакав књижевни лист који уређује, с одабраном 'китом' 'списатеља' и 'књижевника', професор литературе на београдском универзитету".

О Српској граматици Љ. Стојановића (њеном шестом издању) каже: „Пре свега, морам рећи, да Стојановићева Граматика, о којој је овде говор, није самосталан рад. То је дело мање-више компилативне природе, у коме чак има и крупних погрешака" (Бранич 3, стр. 14). У тексту су излистане чак 34 такве грешке са коментарима, на пример: „'Време прошло показује само да је радња недавно прошла, а не гледа се ништа је ли она у свези са каквом другом прошлом радњом или не' (место 'није'). Овде је, пре свега, реч 'ништа' сасвим непотребна. Затим, није истина да време прошло показује радњу која је 'недавно' прошла" (Бранич 3, стр. 14). Међутим, посебно је интересантно што Анђелковић овде скреће пажњу на „бољку” која је и до дана данашњег остала неретка карактеристика штампе, па чак и уџбеничке литературе:

„Узмите готово коју хоћете књигу, или који хоћете часопис, или уџбеник, који је препоручио наш Просветни Савет, па ћете се, ако добро знате језик и правопис српски, уверити каквих језичких и правописних исказа има тамо. Може когод рећи да ја претерујем. Али онај ко не верује у ово што рекох нека погледа, ако је и сам довољно писмен, како пише већина наших песника, књижевника, учитеља, свештеника, професора, лекара, инжињера, официра и судија, па ће видети да је онако, као што рекох. Стога је неопходно потребно, да се одсад обраћа много већа пажња на језик и правопис у свима књигама уопште, а нарочито у онима што су написане за ђаке и школску употребу” (Бранич 3 , стр. 11).

Прота је критиковао и значајне установе, не остављајући по страни, како показује и наведени цитат из новина Правда, ни Академију наука. Могло

\footnotetext{
${ }^{3}$ Станојловић (2009: 11) утврђује „да је комплетан аутор скоро свих прилога у овом надасве оригиналном филолошком часопису био његов уредник и издавач - прота Милош С. Анђелковић. Само у два броја јавља се једини сарадник листа, учитељ из оближњег села Врановца [код Јагодине], Бора Р. Младеновић”.
} 
би се рећи, заправо, да му је Академија и била „омиљена” мета. У рубрици „Разно” Бранича (бр.7, стр. 14) налази се кратак осврт на почетак стварања Академијиног Речника, где Анђелковић изражава велико неповерење и сумњу да ће подухват израде Речника уродити плодом:

„Академија наука, како јављају једне новине, у свом Лексикографском Одељку припремила је грађу за оглед Академијина речника. За уреднике огледа изабрани су: секретар Лексикографског Одељка Момчило Иванић, професор гимназије, и професори универзитета: др Александар Белић и др Василије Ђерић, који ће тај посао радити независно један од другога. Кад доврше поверени им посао, утврдиће се правац и облик уређивања Академијина речника и одредиће се његов уредник.

Ако оглед г. Белића, што се тиче језика и правописа, буде онакав као што су му, у том погледу, 'Дијалекти источне и јужне Србије', онда ће 'прекрасан' бити Академијин речник. Не знам само шта ће онда рећи кудикамо веће лингвисте, као: Новаковић, Будмани, Живановић, Маретић, Живко Стефановић и друге лингвисте у нас и ван краљевине Србије".

Без обзира на недостатке које је имала, Иванићева огледна свеска штампана 1913. (в. Грицкат Радуловић 1988: 27) могла је послужити као полазна основа за наставак рада на Речнику, али се „рад на Речнику угасио смрћу Момчила Иванића 1916. г. За време аустро-немачке окупације Србије (од 1915 до 1918 г.), када је највећи број интелигенције био или на бојном пољу или изван земље, није се могло ни очекивати продужење тога рада" (Белић 1959: XVI). Белић наводи све потешкоће које су у тим деценијама пратиле и практично онемогућавале рад на Речнику (који је још 1887. године иницирао Стојан Новаковић): лоше стање затеченог материјала двадесетих година XX века, незаинтересованост сарадника, пропадање библиотеке са изворима и осталог материјала услед дугог временског периода слабих или никаквих активности (в. Белић 1959). Све у свему, прота Анђелковић као да је антиципирао дуготрајне почетне проблеме са Речником. Треба напоменути и то да је Маретић, кога Анђелковић наводи као једног од великих лингвиста, упутио две суштинске критике Иванићевом огледном издању. Једна је обимност а друга што је изостављено „име хрватско” (Белић 1959: XII). Са првом се Белић не слаже, док на другу каже: „То се толико само по себи разуме да нам није потребно на том се дуже задржавати, али је Иванић то урадио знајући колико је мало хрватских писаца унео у Речник” (Белић 1959: ХІІ).

Осим критика упућених онима који се баве савременим стандардним језиком, прота је упућивао и критике цркви, тражећи да се и богослужбени језик приближи народном. Пилиповић (2017: 232) наводи цитат из Анђелковићевог текста „Богослужбени језик”: ${ }^{4}$ „Руске и грчке богослужбене књиге оставимо Русима и Грцима, а за српску цркву, то јест српски народ и српско богослужење, тако Вам Бога, стварајте, што пре, богослужбене књиге у српском народном духу, с обзиром на стање и потребе Српске Цркве”. Овакве његове идеје и

${ }^{4}$ У: Весник Српске Цркве-орган свештеничког удружења, XXVII, март-април 1921, стр. $127-135$. 
залагања показују да је његово интересовање за српски језик било огромно, а да је енерија коју је улагао како би скренуо пажњу на значај матерњег језика и потребу неговања српског језика, најблаже речено, импресивна.

\section{ПРОТА АНЋЕЛКОВИЋ ПРОТИВ АЛЕКСАНДРА БЕЛИЋА}

Већ на првим странама првог броја Бранича види се делимично ироничан тон којим Анђелковић говори о Белићу у вези са писањем тачке и запете „при крају врста у натписима на књигама и иначе, у тексту” (Бранич 1, стр. 2). Износећи ко од филолога (Вук, Даничић, Стојановић и други) како практикује употребу тачке или запете у оваквим ситуацијама, он каже да Белић (наравно, не пропуштајући да га одреди као доктора филологије) ,щара, то-јест и он час ставља тачку при крају врста у натписима у тексту, а час пак не ставља" (Бранич 1, стр. 4). Анђелковић у фуснотама детаљно потврђује и један и други Белићев начин писања. Међутим, то је само благ увод у завршницу првог броја часописа, која почиње од 12. стране у рубрици „Критика и кратки прикази” приказом Белићеве књиге Дијалекти источне и јужне Србије. Већ на самом почетку Анђелковић има кључну примедбу на Белићев метод рада (и цитира део текста у којем он сам каже да није обишао одређена места да би утврдио границе дијалекта) $)^{5}$. Бесно закључује: ${ }^{6}$, „вћ се у том тако важном послу ослонио на бугарске писце и некакве податке 'ca стране'. Међутим колико је и могућно замислити да бугараши могу бити непристрасни кад говоре о дијалектима јужне, а нарочито источне Србије, то, мислим, знају и бабе сеоске" (Бранич 1, стр. 13). Кључ, дакле, иницијалних сукоба између Анђелковића и Белића јесте протина велика осетљивост за национална питања, а не само филолошка. Не бирајући речи (нпр. бугараши) нити начине да формулише своје ставове („то знају и бабе сеоске”), закључује чак да је Белић био „под утицајем бугарских и других писаца при одређивању граница источних и јужних дијалеката" (Бранич 1, стр. 13). А овај став у сасвим заоштреном облику изнеће на суђењу из 1927 . године, узимајући управо ову студију као

${ }^{5}$ На самом почетку студије Белић детаљно наводи где је све ишао на својим „екскурзијама” да би што пажљивије одредио границе дијалеката (Белић 1905: XXIX-XXXII) и каже да се сећа „са посебном захвалношћу” оне који су му „посао олакшали”: „Мило ми је што могу констатовати да су у овоме наши учитељи предњачили пред осталим: нека им је на томе моја искрена хвала!” (Белић 1905: XXXII). Анђелковић не подвлачи да је Белић предузео опсежан теренски рад, него само бурно реагује на следећи део текста: „Границе овим дијалектима нити су природне с источне нити с јужне стране. Зато је сасвим разумљиво што се различни говори ових дијалеката пружају у западну Бугарску и источну Ст. Србију. Ја нисам имао прилике да са̂м проучим те говоре у реченим земљама, па сам за то принуђен да упутим читаоца на границе њихове које нам дају Цоневъ и Милетичъ и које сам и ја сам могао да одредим по подацима које сам са стране добијао" (Белић 1905: XLVII-XLIX).

${ }^{6}$ Сва истицања у цитираним деловима текста су оригинална. 
доказ да је Белић зарад високог положаја политичке критеријуме стављао изнад научних (Правда):

„Међутим, продужава г. Анђелковић, чак и Бугарин П. Славејков каже да су Шопови, по говору и нормалним особинама, Срби и по мало Бугари из зајечарског и неготинског округа. Тврђење ово П. Славејкова налази се на 54. страни поменуте књиге г. Белића. Али, како у зајечарском и неготинском округу нема Бугара, јер су тамо чисти Срби, то значи да и сам Бугарин Славејков признаје да су Шопови исти ${ }^{7}$ Сби, док Србин, г. Белић, доказује да се Шопови приближују маћедонским и бугарским Словенима, и ако се зна да центар Шоплука чине ова места: Радомир, Ћустендил, Свети Никола, Кратово, Врање, Ниш и Пирот"в.

У чланку у Браничу Анђелковић истиче и наводи потврде од Вука до савремене литературе везане за именице на -иште, да Белић није у праву кад, како сам каже, претпоставља да је пепелиште, као и пилиште, дошло из бугарског језика. Налази, тврди, преко 500 језичких и правописних погрешака и излистава многе од њих, али посебно замера Белићу непрецизност која не може бити примерена „научним изразима”: „изгледа ми”, „морамо претпоставити”, „сад не могу казати” (Бранич 1, стр. 14). Чланак завршава реченицом „Ову Белићеву књигу издала је Српска Краљевска Академија!” (Бранич 1, стр. 15).

Први број Бранича објављен је 1. јануара 1907. године, а после само два месеца, 1. марта исте године, Анђелковић већ одговара „Милораду Јанковићу, сирјеч Александру Белићу, професору универзитета" поводом чланка који је у Српском кьижевном гласнику (часопису који је, како смо видели, прота такође повремено оштро критиковао) од 1. фебруара објавио „Милорад Јанковић, ученик г. Александра Белића, професор филологије на нашем унверзитету" (Бранич 4-5, стр. 17-18). Анђелковић одмах изражава сумњу у идентитет аутора текста: „Да ли је ту књижевну наказу и написао, или ју је само потписао ученик г. Белића - не знам, нити хоћу то да знам. Али хоћу да упознам читаоце 'Бранича' са садржином те Милорадо-Белићеве књижевне накараде" (Бранич 4-5, стр. 18).

И заиста, Јанковић (иза чијег имена Анђелковић готово увек додаје „сирјеч Александар Белић”) у том тексту прави одређене омашке које је прота спремно „дочекао на нож”. Пишући „Г. Прота” великим словима, аутор Анђелковићу даје пуно право да одговори: „Јанковић, сирјеч г. Белић, вели: испао сам 'жалосно смешан' што говорим о правопису јер то знају и ђаци, а 'људи од књиге (овакви, као г. Јанковић и г. Белић) слабо воде рачуна о таквим стварима',

${ }^{7}$ Вероватно треба: „чисти”, претпостављамо да је штампарска грешка у Браничу.

${ }^{8}$ Овако Белић (различито од Цвијића, што сам наводи) износи тај став на који Анђелковић, између осталог, реагује: „Јер треба имати на уму, 'да Шопови' по ономе чиме се одликују од Срба не представљају ништа спеиифично, чисто шопско, већ се приближују околним македонским и бугарским Словенима [...] Кад је тако са језиком, по свој је прилици тако и са главним етнолошким цртама" (Белић 1905: LVI). 
jep су 'безначајне'. Дакле, по схваћању г. Јанковића и учитеља му г. Белића, 'безначајно је' ако се напише 'Професор', 'Прота', 'удали', 'безпослен' и т. д., као што они пишу" (Бранич 4-5, стр. 19). На Јанковићеву опаску да је једно од питања интерпункције које је Анђелковић замерио Белићу решено давно пре но што је „проти пало на памет да га решава”, Анђелковић самоуверено одговара: „Али ја чикам и ђака и учитеља му г. Белића да кажу: где је, сем 'Бранича', написана ма и једна врста о томе питању" (Исто, стр. 19). Међутим, оно где Јанковић даје заиста велики повод Анђелковићу да реагује јесте реченица која је цитирана цела, а која гласи: „Књижевни је језик обично најраспрострањенији дијалекат једног језика који у току времена може да се удали од говорног језика”. Прота истиче да је ово „права бесмислица”, „крајње незнање” ,jер књижевни језик није, нити може бити, дијалекат, пошто не постоји народни или дијалекатски књижевни језик, већ се, напротив, књижевни језик ствара по основима народног или дијалекатског говора. Зато се тај књижевни језик и сматра као ицар и круна дијалектима, јер обухвата оно што је у њима најлепше, најправилније и најопштије" (Бранич 4-5, стр. 18). Прота Анђелковић овде, као и у многим другим питањима везаним за језик, показује знање и добру обавештеност са којима се обрушава на сваку погрешку свога опонента, било колико да би се могло претпоставити да је у питању и омашка.

Права кулминација Анђелковићевог односа према Белићу, међутим, наступа после објављивања правописа. Колико је био огорчен, јасно је из чињенице да је 1926. године објавио не чланак већ књижицу (коју назива брошуром) са дугим насловом Питање о правопису српског или хрватског језика или Кривопис д-ра Александра Белића, професора филологије у београдском университету. Од корице па до последње стране инсистира на одговорности Академије наука. Посветивши брошуру „најозбиљнијој пажњи Академије Наука и Главног Просветног Савета", већ у уводу каже да Министарство просвете има право што је одредило компетентну комисију за израду правописа (позивајући се на текст у Политици), али да „д-ра Александра Белића ни у ком случају није требало узимати у ову комбинацију, јер је то човек који је не само својим 'Правописом Српскохрватског Књижевног језика' с 'Правописним речником' него и свима својим досадашњим радовима о правопису еклатантно доказао да није за тај посао" (Анђелковић 1926: 4). У намери да то и докаже, он наводи све „непринципности” и „нелогичности” које је Белић унео у Правопис Српскохрватског књижевног језика (Правопис 1923) у жељи, како прота процењује, „да замени Вука” (Исто: 6). Анђелковића највише иритира то што Белић уводи иновације које су по њему неосноване (нпр. „хиперфонетички" правопис) и што сугерише „да је Вук застарео”, посебно у тексту $O$ савременом правопису српскохрватског језика (Белић 1923). Заиста, Белићеви погледи на реформу правописа и разлози које за њу наводи упућују на такав закључак. Он, између осталог, каже: „Али је сада питање да ли се неће и Ка- 
раџићев правопис претворити у историски, ако се за сва времена задржи све онако како је Вук предложио" (Белић 1923: 159), те ову своју бојазан - због које уводи једначење $\partial$ испред $c$ и $u$ - сликовито илуструје:

„Прави је разлог у томе што је ова прва крупнија недоследност Вукова правописа повукла за собом многе друге, тако да нам је целокупна правописна система Караџићева у опасности. Као микроб који се једно време притајио, па се после тога почео са великом брзином размножавати, тако је ова аномалија постала углед за нове аномалије, које су већ толико многобројне да је несумњиво да ће изазвати још многобројнија нова отступања. Зато је најбоље излечити зло у самом корену. Да је Караџић знао да ће ова његова свесна грешка против система имати оваквих последица, он је зацело не би учинио" (Белић 1923: 166).

Изузетно изиритиран оваквим Белићевим ставовима и иновацијама које су се удаљиле од Вукових решења, прота Анђелковић у брошури детаљно анализира ставку по ставку, напомињући и да је Правописни речник Белићев ,још гори”, те да је направио његову опсежну критику „у рукопису две стотине и тридесет полутабака" (Анђелковић 1926: 5). Прве две целине брошуре, после уводног текста, посвећује писању $j$, где тврди да Белић „квари из основа наш правопис" (Исто: 7) својим решењима којима се писање $j$ регулише према томе да ли је „слабо” или ,јако”. Тако је, на пример, дошло до тога да Белић заступа изостанак слова $ј$ у присвојним придевима изведеним од именица које садрже $j$ у основи (Правопис 1923: 23). Анђелковић оштро протестује против фаворизовања фонетског критеријума, који се своди на релативно произвољни и свакако несистемски „(не) чује се у говору”: „У Ресави, например, слушам ја већ 40 година само: моа жена, моа рука, моа кола, моа кућа, моа њива, твоа деца, твоа ливада, моега и твоега оца; моима и твоима, моих и твоих и т. д. И обрнуто: зар и не говори и не пише сваки Србин на свету, осим г. Белића, само: специјалан, дијамант, пијавица и т. д.” (Анђелковић 1926: 8).

Трећи одељак је по Анђелковићу и најзначајнији јер скреће пажњу на решење којим Белић „уноси највећи хаос у наш правопис” (Исто: 9). То је једначење $\partial$ испред $c$ и $и$ у писању. На Белићево решење одговориће да би оно довело до „апсурда и бесмислица” јер „потамњује основу, а и само значење речи” (Исто: 9). Белић ово решење аргументује тиме што ово „отступање” може довести и до лоших последица: „Под утицајем ових отступања почиње се и другде остављати неизмењен звучни сугласник пред муклим: пише се подпуковник, подпредседник и т. д. Овде се види да ова отступања почињу нарушавати цео систем нашег правописа у овом правцу, међутим она нису ни најмање ни оправдана ни потребна" (Правопис 1923: 46).

Наредни одељак прота Анђелковић посвећује критици Белићевих решења везаних за бележење фонеме $x$, која се заснивају на ставу да се $x$ пише свуда где је етимолошко. Оштрије него у брошури, прота иступа против овог решења на судском рочишту 1926. године, којем је, према писању Политике, присуствовао „силан свет”, велики број професора Универзитета, па и Станислав Винавер. 
Анђелковић износи своју аргументацију која се, према новинском чланку и обради Милована Витезовића, допала Винаверу:

,’Још нас доктор Белић учи да пишемо: аждаха, кихати, кихавица, махрама, трухлети, мехлем, хендек, Хавала уместо Авала, па и хисторија уместо историја', свештеник Милош Анђелковић је претпоставио примену ових правила: 'Јер не морају само наши писци да зехају, имају кихавицу и бришу нос махрамом, већ треба да пију кахву и беру босилак. Не сме се брбљати него је допуштено само брблати. Али нека зеха и киха онај који прописује правила за зехање и кихање, а српски народ није никад зехао, кихао и брблао, па неће никад зехати, кихати и брблати...' У дворани је настао смех, који је једино све више надјачавао глас Станислава Винавера. 'Ово је пародија!' - улетео је глас господина Живка Тадића, адвоката академика Александра Белића. 'Пародија служи да истина буде тачна и прецизна!' - викао је Станислав Винавер: 'А хумор је чини супериорном, непоткупљивом и убедљивом. Зато је хумор дар истине. Зато хумор боли колико истина"”. (Политика, 26. 1. 2016)

Станислава Винавера са овог суђења извела су, према сведочењу Политике, два жандара јер је правио ларму и ометао процес, инсистирајући да му судија одговори на питање како може да пресуђује о „питањима закона језика”. На то му судија одговара да себи превише дозвољава, а потом следи читава бура у судници која започиње Винаверовим ироничним одговором:

„'Није то ништа према ономе што сте Ви себи дозволили. За законе језика у овој судници од Вашег судског већа овлашћенија је свака клупа у публици. Пред Вама је цвет нашег Университета, и наше Академије, такорећи национална ботаничка башта.'

У судници је био тајац. Судија је и поред тишине ударао чекићем. 'Како Вас, господине судија, није срамота да ту седите? На почетку је требало да са неким замените место. Хоћете ли да ја одредим судско веће? - праскао је Винавер. 'Господине, напустите судницу!' - викао је судија Вукајловић. 'После Вас, господине.' 'Избаците господина из суднице!' - лупао је чекићем и звонио звоном председник судског већа. Винавера је пренеразила тишина у публици. На позив председника судије Вукајловића, Станиславу Винаверу су пришла два жандарма и узела га под руку. Винавер се није опирао. 'Шта је, господо? Ћутите? О вашем језику се суди!'”

Но, да се вратимо Анђелковићевој брошури. Њен наредни одељак посвећен је решењима која прота сматра изузетно конфузним. То су правила везана за поделу на слогове и упрошћавање сугласничких група (типа пmuй, пшенииа, према лопта, в. Правопис 1923: 52). У овом одељку прота је ипак конфузнији него Белић јер заступа „редуцирање” сугласника $n$ исред $m$ или $u$ „зато, што он није апсолутно потребан” (Анђелковић 1926: 11) пошто његов изостанак не замагљује значење речи.

Да је Белић „начинио дармар” (Исто: 11) у сегменту о писању великог слова, прота документује тиме што уместо речи слова Белић користи термин писмена, а потом и тиме да је непрецизан у формулацијама: ,'Све што је назив или име предмета или лица пише се великим писменима'. Дакле према овом правилу треба писати: ЧОВЕК, РУКА, КЛУПА, САВА, ДУНАВ, АВАЛА, ЂУРЂЕВО БРДО, МИЛОШ, МАРКО, ИЛИЈА и т. д. (све великим словима), а то је најблаже да се изразим, којешта" (Исто: 12). Дакле, Анђелковић овде 
заоштрава реакцију на очигледну Белићеву омашку и доводи до апсурда решење које би се дословно применило.

Још је већа „посластица” проти стигла сама од себе. Наиме, Белићев Правопис (1923) уместо речи интерпункција садржи погрешно одштампану реч интерпукuија. На ову омашку и сам Белић упућује у напомени у тексту $O$ савременом правопису српскохрватског књижевног језика (Белић 1923: 184): „У 'Правопису’ и поред мојих исправака у коректури, провукло се три пута 'интерпукција' на стр. 127'. Међутим, прота је решен да не опрости било какву правописну и терминолошку грешку у правопису и, наводећи ову Белићеву напомену, одговара: „Међутим, поштовани читаоци, то није истина. Да, није истина што каже г. Белић да се трипут случајно провукло 'интерпукција', него је Белић кроз целу књигу писао само 'интерпукција' и ниједанпут није написао интерпункција" (Анђелковић 1926: 12). Следи детаљна елаборација о томе како Белић у сопственом тексту употребљава интерпункцијске знаке, са наведеним примерима. На основу тога Анђелковић закључује, не бирајући речи да би критику учинио пристојнијом, да је у овој области Белић „лаик”, да ,појма нема”, да „увек душмански гази и игнорише правила о интерпункцији” (Исто: 13).

У наредном, деветом одељку, ништа мање не критикује ни правописни речник који је, по њему, „књижевна ругоба” за коју аутор тврди да није било довољно „претходних радова” на које би се могао ослонити. „Нема, заиста, велим и ја! Али за кога нема? За онога који не познаје литературу" - одговара прота (Анђелковић 1926: 15). Наводећи листу од тридесетак библиографских јединица, закључује да материјала има, „само треба знати где је” (Исто: 17).

И, на крају, постоји још један сегмент на који се Анђелковић осврће, а у којем реагује посебно афективно. То су више национална него језичка питања, а у вези са њима прота не сакрива емоције и не штеди најоштрије речи. Започиње га правописним проблемом писања назива српскохрватског језика. Назив, како каже, треба писати са цртицом или, још боље „српски или хрватски" јер је реч о истом језику. Наводећи да тако пишу и Даничић и Маретић, износи вероватно и најзначајнији сегмент своје критике који је, наравно, сачувао за крај брошуре, а који усмерава колико на Белића толико и на Академију наука:

„Само је г. Белић нашао да је данас, и то баш данас, мудро, научно и политички умесно не сматрати да је српски језик исто што је и хрватски језик, ваљда зато, да тиме још више манифестује и појача јединство Срба и Хрвата, који су заиста и по језику и по крви један народ.

Како је почео г. Белић можда ће нам он ускоро дати и правопис о српскоцрногорском књижевном језику, а можда и правопис српскобосанског језика, или и какав правопис српскохерцеговачког језика.

[...] Ја много осуђујем Академију Наука, што једном не забрани г. Белићу да квари српски језик и српски правопис. Ако тамо има Срба то треба учинити макар сад. [...] Чуј 
и разумеј ово Академијо Наука! ако те има и ако си жива после Стојана Новаковића!” (Анђелковић 1926: 22)

Ово није било довољно Анђелковићу, већ свој апел интензивира грубо се позивајући на националност Александра Белића, што је кулминација његових реакција од двадесетак година раније поводом Белићевих писања о „Шоповима". Изјављујући још на почетку брошуре да Белићу не треба поверити израду правописа „будући да није ни Шумадинац, ни Херцеговац, ни Рудничанин, ни Ваљевац, ни Подринац или какав Сокољанин” (Анђелковић 1926: 4), на крају закључује да Белић „као човек сасвим друге расе, као човек чија душа нема апсолутно никаквог сродства с нашом српском душом, и као човек коме сама крв смета да буде Вук, Даничић, Новаковић и Маретић, требало би да је скромнији, а не оволико претенциозан, да нас Србе чак толико вређа, дискредитујући и омаловажавајући, директно и индиректно, бесмртнике: Вука, Даничића и Новаковића" (Исто: 23). У томе што Академија није изнела став и суд о Белићевом Правопису из 1923, прота види „нешто што нећу да кажем, јер засад нећу и њу да нападам" (Исто: 24). Није, међутим, тешко закључити да Анђелковић алудира на однос Академије према националним питањима, јер ову реченицу ставља у оквире текста у којем се искључиво говори о националним темама, а који окончава инсистирањем „да је за решавање питања која се тичу српског језика способан само Србин [...] Зато ја тражим од д-ра Белића да не дира ни наш језик ни наше великане онако исто као што ми не дирамо у Талмуд!” (Исто: 24).

Можда би се, да прота није овако променио циљ своје брошуре и усмерио свој бес на питање националности Александра Белића, позване институције и позабавиле неким протиним сугестијама везаним за правопис. Можда ни Белић не би реаговао иако је сукоб међу њима двојицом одраније добио размере „сензације” која је „ширила свој терен, поглавито у Првостепеном Суду” (Прав$\partial a)$. Међутим, Белић реагује управо на овај део протине брошуре и упућује му отворено писмо (Политика од 18. 7. 1926, бр. 6547) у којем наводи: „нико од мојих предака није био ништа друго до Србин” и тврди да га је Анђелковић оклеветао, да га је „опадао” и изнео низ нетачности. Ово је био повод да Анђелковић тужи Белића за клевету и да се још једном (1927. године) нађу у судници. Међутим, Белић се на том суђењу (о којем извештава Правда) не појављује, већ упућује писмени одговор и шаље адвоката-заступника.

На крају, остаје питање какав је резултат имао овај прави, најмање двадесетогодишњи, рат између проте Милоша Анђелковића и Александра Белића, ова серија „филолошких мегдана” које је јавност Србије пратила са огромним интересовањем. Можемо рећи да се прави епилог догодио дуго после протине смрти, када је у правопис враћен низ елемената за које се он лавовски борио. Далеко од тога да је по сваком питању био у праву (заступао је неке ставове који немају филолошко утемељење), а још даље од тога да је 
иступао са правом мером срџбе и пристојности. Међутим, јасно је да је у то доба препознао почетке многих по српски језик и писмо опасних процеса који су довели до несагледивих последица.

И велика љутња коју је прота Анђелковић испољио у вези са „Шоповима” има своју невеселу аналогију у данашње време. То је полемика везана за торлачки језик који се, заједно са арумунским, банатским бугарским, сефардским, ромским и војвођанским румунским нашао у Унесковом Атласу угрожених језика са ,алтернативним називима” (горански, јањевски, карашевски) (в. Одлука ОССЈ од 26. 2. 2019). Географска зона ових говора не само да је довела до тога да они буду посматрани као прелазни, ${ }^{9}$ већ и до посебне осетљивости на сам термин: „данас назив Торлак на интернету налазимо најчешће у препуцавањима српских, бугарских и других националиста о торлачком дијалекту и Торлацима, у смислу говора и становништва овог широког простора (Крстић 2014: 646). Осим таквих лаичких реакција, из сличних је разлога дошло до полемике поводом зборника Тимок. Фолклористичка и лингвистичка теренска истраживања 2015-2017. (Ћирковић 2018; в. Карановић 2018; Ћирковић 2018a).

Термин торлачки „коришћен је у прошлости у стручној литератури за именовање говора читаве призренско-тимочке дијалекатске области" (Одлука ОССЈ од 26. 2. 2019), а Белић је чак придодао и термин шопски: „Сем ресавске акценатске системе има и тимочка (шопска или торлачка)" (Белић 1938: 135). Слично као у протино доба, „посебну обазривост код третирања ПТ говора изискује и чињеница да аспирације према делу српских говора налазе свој одраз, нажалост, и данас на картама Бугарског дијалектолошког атласа" (Одлука ОССЈ од 26. 2. 2019).

У неком се облику остварило чак и оно што ни Анђелковић није сматрао могућим и што наводи као крајњи апсурд, а то је да добијемо и „српскобосански”, „српскоцрногорски” правопис. Коначно, без обзира на то колико је који од двојице филолошких мегданција био у праву или криву, „цртица” из историје српског књижевног језика коју смо у раду описали пре свега треба да укаже на пажњу коју су некада и интелектуалци других профила и грађанство посвећивали српском језику, правопису и писму, али и да послужи као

${ }^{9}$ Овај термин користи и Ивић: „појаве које обједињују све говоре те области по правилу се могу наћи и код суседа, било на једној или на другој страни. То даје призренско-тимочкој дијалекатској области изразито прелазни карактер" (Ивић 2018: 225-226). Међутим, Белић, очигледно увиђајући могућност произвољних тумачења, истиче (курзив оригиналан): „Према свему овоме јасно је да ови наши говори нису прелазни у смислу смешаних говора нити су спојни нити нешто слично. Они представљају у основи својој српске говоре за које се, несумњиво, може утврдити да се један ғихов део, пошто је неко време проживео са осталим шток. говорима заједничким животом, одвојио од остале масе њихове до почетка XIII века, почео од тада, доста прогресивно, да се развија" (Белић 1905: LXXXIV). 
својеврсна опомена да без такве пажње време доведе до последица које се некада нису могле ни замислити.

\section{ИЗВОРИ И ЛИТЕРАТУРА}

Анђелковић 1923: М. Анђелковић, Хришћанска наука за ученике и ученице средњих школа, према програму израдио прота Милош С. Анђелковић, начелник Министарства вера (друго издање допуњено према напоменама Главног просветног савета), Београд: Издање Свесловенске књижарнице М. Ј. Стефановића и Друга.

Анђелковић 1926: М. Анђелковић, Питање о правопису српског или хрватског језика или Кривопис д-ра Александра Белића, професора филологије у београдском университету. Посвећено најозбиљнијој пажьи Академије Наука и Главног Просветног Савета. Београд: Дом.

Анђелковић 1928: М. Анђелковић, Историја хришћанске и српске иркве, Београд: Књижарница Милојевића и Павловића.

Анђелковић 1930: М. Анђелковић, Догматика православне иркве с апологетичким објашьенима за VI разред гимназије (треће издање), израдио прота Милош С. Анђелковић, начелник Министарства Вера у пензији, издање Књижарнице Милојевића и Павловића.

Белић 1905: А. Белић, Дијалекти источне и јужне Србије, Српски дијалектолошки зборник, књ. I.

Белић 1938: А. Белић, Позоришни језик, Наш језик, VI/5-6, 129-136.

Белић 1959: А. Белић, Увод у: Речник српскохрватског књижевног и народног језика, књ. 1. Београд: Српска академија наука и уметности, VII-XXVI.

Белић 1999: А. Белић, О савременом правопису српскохрватског књижевног језика, у: А. Белић, Правописи, свеска 1: Правописи. Белић о правописима. Граматичка терминологија, Изабрана дела Александра Белића, Београд - Нови Сад: Завод за уџбенике и наставна средства - Будућност, 159-190.

Бранич: Бранич српског или хрватског језика. Први лингвистички лист, искључиво за исправљање погрешака у језику и правопису српском или хрватском. Власник и уредник прота Милош С. Анђелковић, професор јагодинске учитељске школе Јагодина (бр. 1 од 1. јануара 1907. г.; бр. 3 од 1. фебруара 1907. г.; бр. 4-5 од 1. марта 
1907. г.; бр. 7 од 1. априла 1907. г.; сви бројеви штампани су у Јагодини, „у штампарији Ђорђевића и Гилића”).

Време, дневне новине, 12.2.1928.

Грицкат Радуловић 1988: И. Грицкат-Радуловић, Речник Српске академије наука и уметности - почеци, лик, перспективе, Глас Српске академије наука и уметности књ. CCCLII, Одељење језика и књижевности, књ. 13, Београд: САНУ, 25-40.

Годишњи извештај 1900/1901: Српска Краљевска Мушка учитељска школа у Јагодини,Трећи годишњи извештај 1900-1901. школска година, приредио Сретен М. Аџић, управитељ, штампано у штампарији код „Просвете” у Београду 1901.

Годишњи извештај 1901/1902: Српска Краљевска Мушка учитељска школа у Јагодини, Четврти годишњи извештај 1901-1902. школска година, приредили Сретен М. Аџић, управитељ, Милан А. Тодоровић, деловођа, штампано у штампарији код „Просвете” у Београду 1903.

Годишњи извештај 1905/1906 и 1906/1907: Српска Краљевска Мушка учитељька школа у Јагодини, Осми и девети годишњи извештај 1905-6 и 1906-7. школска година, приредили Сретен М. Аџић, управитељ, Милан А. Тодоровић, деловођа, штампано у штампарији Шорђевића и Гилића у Јагодини.

Годишњи извештај 1908/1909: Српска Краљевска Мушка учитељска школа у Јагодини, Једанаести годишьи извештај 1908-1909 школска година, уз помоћ више наставника приредио Сретен М. Аџић, управитељ, штампано у штампарији код „Просвете” у Београду.

Двадесетпетогодишњица МУШЈ: Двадесетпетогодиюица Мушке учитељске школе јагодинске, са 21 сликом у тексту, израдио Јосиф В. Стојановић, управитељ. Јагодина, 1924.

Ивић 2018: П. Ивић, Расправе, студије, чланции. 2. О дијалектологији, Целокупна дела Павла Ивића X/2 (прир. С. Реметић), Сремски Карловци - Нови Сад: Издавачка књижарница Зорана Стојановића

Карановић 2018: 3. Карановић, Понешто о причању и генерисању приче и о стварности, пре свега, Фолклористика, 3/2, 193-200.

Кострешевић 2012: М. Кострешевић, Епископ захумско-херцеговачки др Тихон Радовановић и његов допринос развоју српске богословске мисли, у: Гласник Удружења архивских радника Републике Српске, IV/4, 181-190. 
Крстић 2014: Д. Крстић, Конструкција идентитета Торлака у Србији и Бугарској, [докторска дисертација], Филозофски факултет Универзитета у Београду http://147.91.75.9/manage/shares/disertacije/ Krstic_Dejan_2014-11-06.pdf (преузето 10.8.2019).

Кубат 2008: Р. Кубат, Тихон Радовановић „први српски старозаветник”, у: Б. Шијаковић (ур.) Српска теологија у двадесетом веку: истраживачки проблеми и резултати, књ. 3, Београд: Православни богословски факултет, 7-15.

Кубурић 2010: 3. Кубурић, Верске заједнице у Србији и верска дистанца, Нови Сад: CEIR.

Ћирковић 2018: С. Ћирковић (ур.), Тимок. Фолклористичка и лингвистичка теренска истраживања 2015-2017. Едиција „Књажевачким крајем”, књ. 9, Књажевац - Београд: Народна библиотека „Његош" - Удружење фолклориста Србије.

Ћирковић 2018а: С. Ћирковић, Одговор на приказ зборника радова Тимок. Фолклористичка и лингвистичка теренска истраживања 2015-2017, Фолклористика, 3/2, 201-208.

Одлука ОССЈ од 26. 2. 2019: Одлука Одбора за стандардизацију српског језика Српски говори призренско-тимочке дијалекатске области (нацрт Одлуке сачинила др Софија Милорадовић), http://www. ossj.rs/odluke-i-saopstenja/prizrensko-timocki-govori/ (преузето 10. 8. 2019)

Пилиповић 2017: Р. Пилиповић, Српска православна ирква, Руска православна загранична ирква, Московска патријаршија (1920-1940) - узајамне везе, утицаји и односи, [докторска дисертација], Филозофски факултет Универзитета у Београду. http://nardus. mpn.gov.rs/bitstream/handle/123456789/10627/Disertacija.pdf?seq uence $=1 \&$ is Allowed $=\mathrm{y}$

Политика, дневне новине, 18. 7. 1926, бр. 6547

Политика, дневне новине, 26. 1. 2016: Милован Витезовић, Срби никада нису говорили сутски него судски (обновљено према писању Политике) http://www.politika.rs/sr/clanak/347867/Srbi-nikadanisu-govorili-sutski-nego-sudski (преузето 2. 8. 2019)

Правда, дневне новине, 4. 10. 1927. (бр. 269)

Правопис 1923: Правопис српскохрватског књижевног језика, Београд: Издавачка књижарница Геце Кона. 
Правопис 1960: Правопис српскохрватскога књижевног језика, Нови Сад - Загреб: Матица српска - Матица хрватска.

Станојловић 2009: Н. Станојловић, Протојереј Милош С. Анђелковић (1868-1931), катихета Мушке учитељске школе јагодинске, у: Поморавски олтари, књижевни часопис о ирквама и манастирима, сепарат „Гороцвета”, бр. 2-12, Јагодина, 9-13.

\section{ON ONE SESSION OF "PHILOLOGICAL DUELS"} A dash from the history of Serbian literary language

\section{Summary}

The paper presents data and details related to the long-standing conflict between the archpriest Milos S. Andjelković and Aleksandar Belić. The conflict, apparently, was initiated by the priest Andjelković at the time when he was a professor at the Teacher Training School in Jagodina. Except that the conflict was handled in writing (magazines, primarily "Branič", whose owner and editor was priest Anđelković, daily newspapers, brochures), the conflict was also transmitted to the Belgrade City Court and attracted enormous attention from philologists, clergy, professors and students, but also to the general public. The trials were followed by the press at the time and reported in detail, which is the source we used in the paper.

The paper first provides basic information about Anđelković's life and work, and then shows his interest in the issues of the Serbian language, including the requirements for the liturgical language to be adapted to Serbian and to become more understandable to believers. The central part of the paper provides an overview of the elements of Andjelković's conflicts with Belić. It is shown that the priest has sharply reacted to Belić's study "Dijalekti južne i istočne Srbije" primarily because he identified Šops as a people who "linguistically and ethnologically" came closer to Macedonians and Bulgarians, and because he did not define precisely the boundaries of Serbian dialects in western Bulgaria, but instead followed the Bulgarian literature. He attacked Belić's spelling solutions in Pravopis, published in 1923, extremely hard, and especially those whose spelling deviated from Vuk's basics: writing of "j" and "h", assimilation of "d" in front of "s" and "s", claiming that Belić wanted to "replace Vuk" and that he belittled in that way the great scientists of Serbian philology. And, further, that by the way Belić spells the name "Serbo-Croatian" he shows that he thinks that it is not the same language. Together with Belić, the Academy of Sciences was also the target of Andjelković's fierce criticism, which he also emphasized in the courtroom, because of its negligent attitude towards the Serbian language and Cyrillic.

Keywords: priest Milos Andjelković, Aleksandar Belić, magazine "Branič", spelling, Serbian literary language. 